\title{
Biochemical analysis of germination mutants to characterize germinant receptors of Bacillus subtilis 1604 spores
}

\author{
Padmavathy Venkatasubramanian and Keith Johnstone* \\ Department of Plant Sciences, University of Cambridge, Downing Street, Cambridge CB2 3EA, UK
}

(Received 14 December 1992; revised 26 February 1993; accepted 16 March 1993)

\begin{abstract}
Spores of Bacillus subtilis 1604 can be induced to germinate by incubation in L-Ala (the ALA pathway) or in a combination of $\beta$-D-glucose (Gle), $\beta$-fructose (Fru), L-Asn and $\mathrm{K}^{+}$(the GFAK pathway). Biochemical analysis of the germination response of a ger $A$ mutant deficient in the ALA pathway revealed that L-Ala can replace L-Asn in the GFAK pathway (the GFAlaK pathway). In contrast to the ALA pathway of both the wild-type and of a gerB mutant, the GFAlaK pathway was insensitive to D-Ala and showed the same overall inhibitor profile as the GFAK pathway of wild-type and ger $A$ spores. It is deduced that a second L-Ala receptor with different characteristics to that functioning in the ALA pathway is present in wild-type spores. Analysis of the germination response of a gerB mutant showed that whilst the rate of ALA germination could be stimulated by Glc as well as by Fru in the presence of Glc, the spores could not germinate in GFAK. In addition, Glc and Fru were unable to reverse D-Ala inhibition of L-Ala germination which they do in the wild-type. Thus, in the gerB mutant, the L-Ala/L-Asn receptor in the GFAK pathway is defective. It is concluded that the germination receptors in the ALA and GFAK pathways can functionally interact with each other to initiate $B$. subtilis spore germination. This conclusion is discussed in relation to proposed models of triggering of spore germination.
\end{abstract}

\section{Introduction}

Spores of Bacillus subtilis can be induced to germinate by several combinations of germinants, including L-Ala (ALA system) and a combination of $\beta$-D-glucose (Glc), $\beta$ fructose (Fru), L-Asn and $\mathrm{K}^{+}$(GFAK system) (Wax \& Freese, 1968). The mechanism by which the germinants interact with spore components to initiate germination is not known. Wax et al. (1967) proposed that initiation of $B$. subtilis 168 spore germination can be triggered by germinants entering at least two biochemical pathways. One branch is inhibited by D-Ala or by high temperature; compounds produced in this pathway can also be provided by the combination of Fru, Glc and $\mathrm{K}^{+}$. The products of the other branch could also be produced by L-Asn or L-Gln, either of which alone is unable to initiate germination but also requires Glc, Fru and $\mathrm{K}^{+}$(Wax \&

*Author for correspondence. Tel. (0223) 333933; fax (0223) 333953.

\footnotetext{
Abbreviations: Fru, $\beta$-fructose; Glc, $\beta$-D-glucose; ALA, 1 mM-L-Ala in $50 \mathrm{~mm}$-potassium phosphate buffer, pH 7.4; GFAK, $5.6 \mathrm{~mm}$-Glc, $5.6 \mathrm{~mm}-\mathrm{Fru}, 30 \mathrm{mM}-\mathrm{L}-\mathrm{Asn}$ and $67 \mathrm{mM}-\mathrm{KCl}$ in $50 \mathrm{~mm}$-Tris/HCl buffer, $\mathrm{pH} 7.5$; GFAlaK, $5.6 \mathrm{~mm}-\mathrm{Glc}, 5.6 \mathrm{~mm}-\mathrm{Fru}$ and $30 \mathrm{~mm}-\mathrm{L}-\mathrm{Ala}$ in $50 \mathrm{~mm}-$ potassium phosphate buffer, $\mathrm{pH} 7 \cdot 4$.
}

Freese, 1968). In addition to a co-operative role with $\mathrm{L}-$ Asn, Fru and $\mathrm{K}^{+}$, Glc appears to play other roles in initiating germination. In ALA-initiated germination, it stimulates germination especially at high temperatures, and enhances the observed reversal by Fru of inhibition caused by D-Ala (Wax et al., 1967).

A number of L-Ala analogues including allylglycine, cycloleucine and L-Val can be used in place of L-Ala in initiating germination of $B$. subtilis spores (Irie et al., 1980, 1982; Kanda et al., 1988; Sammons et al., 1981; Woese et al., 1958; Yasuda \& Tochikubo, 1985). In GFAK germination, Glc can be replaced by the nonmetabolizable analogues 2-deoxy-D-glucose or D-allose (Prasad et al., 1972). Moreover, it has been shown that ATP synthesis is not an early germination event in either the ALA or the GFAK systems and that a range of metabolic inhibitors do not affect spore germination (Venkatasubramanian \& Johnstone, 1989). Finally, mutants lacking alanine dehydrogenase (Freese \& Cashel, 1965), pyruvate dehydrogenase (Freese \& Fortnagel, 1969) or glucose dehydrogenase (Rather \& Moran, 1988) germinate normally. Thus, initiation of germination may take place by a biophysical rather than by a metabolic mechanism.

The stereospecific properties of the germinant 
receptors demonstrate that these components of the trigger mechanism must be proteins which may be activated allosterically (Wolgamott \& Durham, 1971). Analysis of B. subtilis PCI219 spore germination has revealed that in the ALA system, a potent germinant, L-Ala, and its competitive inhibitor D-Ala, bind to a common receptor; their amino and carboxyl groups may bind to respective common regions and their methyl group may bind to separate regions which differ in size and electrostatic nature (Yasuda \& Tochikubo, 1985). The stimulatory effect of glucose on L-Ala-binding, and the absence of an effect on D-Ala-binding, confirm the presence of separate regions with respect to their methyl groups (Yasuda \& Tochikubo, 1984). As L-Ala-initiated germination is inhibited quantitatively by various hydrophobic compounds, a hydrophobic environment near the L-Ala receptor was suggested (Yasuda et al., 1978 $a, b$, 1982).

The spore germination pathway in $B$. subtilis has been studied by the use of germination (ger) mutants (Irie $e t$ al., 1982; Lafferty \& Moir, 1977; Prasad et al., 1972; Smith et al., 1977; Trowsdale \& Smith, 1975; Wax et al., 1967). The different types of ger mutants and their responses to amino acids and sugars have been reviewed (Foster \& Johnstone, 1989; Moir \& Smith, 1990). Mutants in some ger loci affect germination in one germinant system without altering the response in others. These include the ger $A$ and gerC loci (Trowsdale \& Smith, 1975; Sammons et al., 1981) required for ALA germination, and the ger $B, f r u B$ and gerK loci required for a germination response in a combination of amino acids and sugars (Moir et al., 1979; Prasad et al., 1972; Strauss, 1983; Irie et al., 1982). Mutants in the gerK locus behave in a similar manner to ger $B$ mutants; their spores do not germinate in the GFAK system and appear to be deficient in their response to Glc, since Glc fails to stimulate ALA-initiated germination or to enhance reversion by Fru of D-Ala inhibition (Irie et al., 1982). Whilst ger $B$ and/or ger $K$ may encode products which interact with components of the amino acid and sugar mixture, the ger $A$ locus might encode an Ala-sensitive receptor in the spore (Moir \& Smith, 1985). Detailed studies of ger $A$ mutants are consistent with this possible interpretation (Feavers et al., 1985; Zuberi et al., 1987).

It has been postulated that spores of $B$. subtilis may contain two classes of receptor which bind L-Ala; one of high affinity which binds L-Ala (and analogues) alone and another which binds L-Ala (and analogues) with lower affinity in the presence of $\mathrm{Glc}$, Fru and $\mathrm{KCl}$ (Sammons et al., 1981). In this paper, a comparative biochemical study of the germination response of spores of ger $A$ and ger $B$ mutants and of wild-type $B$. subtilis 1604 to amino acids, sugars and inhibitors is presented which provides additional evidence for the presence of two L-Ala receptors and further characterizes the interactions between the germinant receptors.

\section{Methods}

Spore formation. Strains of Bacillus subtilis 1604 (B. subtilis $168 \operatorname{trp} C 2$ ), gerA and gerB18 were obtained from Dr A. Moir (Department of Molecular Biology and Biotechnology, University of Sheffield, UK). Spores were prepared at $37^{\circ} \mathrm{C}$ as described for Bacillus megaterium KM (Stewart et al., 1981) and stored at $10 \mathrm{mg} \mathrm{dry} \mathrm{wt} \mathrm{ml}^{-1}$ in distilled water at $-20^{\circ} \mathrm{C}$. Immediately prior to germination, spore suspensions were heat-activated at $70^{\circ} \mathrm{C}$ for $60 \mathrm{~min}$, and cooled on ice.

Spore germination. Germination of spores $\left(50 \mu \mathrm{g}\right.$ dry wt ml $\left.\mathrm{m}^{-1}\right)$ was induced at $37^{\circ} \mathrm{C}$ in three systems as follows: (i) ALA system in which the spores were germinated for $60 \mathrm{~min}$ in $50 \mathrm{~mm}$-potassium phosphate buffer, $\mathrm{pH} 7 \cdot 4$, by the addition of $1 \mathrm{~mm}$ (final concentration) L-Ala; (ii) GFAK system in $50 \mathrm{~mm}$-Tris/HCl buffer, $\mathrm{pH} 7 \cdot 5$, by the addition of $5.6 \mathrm{mM}$-Glc, $5.6 \mathrm{mM}$-Fru, $30 \mathrm{~mm}$-L-Asn and $67 \mathrm{~mm}-\mathrm{KCl}$ for a period of $80 \mathrm{~min}$; (iii) GFAlaK system in $50 \mathrm{~mm}$-potassium buffer, $\mathrm{pH} 7 \cdot 4$, by the addition of $5.6 \mathrm{~mm}-\mathrm{Glc}, 5.6 \mathrm{~mm}-\mathrm{Fru}$ and $30 \mathrm{mM}-\mathrm{L}-\mathrm{Ala}$ for $80 \mathrm{~min}$. These germinant concentrations were maintained in all experiments unless otherwise stated.

The extent of germination in a spore suspension was determined as the percentage of the control loss in $\mathrm{OD}_{600}$ after 60 or $80 \mathrm{~min}$, for the ALA or GFAK/GFAlaK systems, respectively, in a Pye Unicam SP8-200 UV-VIS spectrophotometer fitted with a constant temperature cell-holder. The rate of germination was measured as the maximum rate of loss of $\mathrm{OD}_{600} \mathrm{~min}^{-1}$ divided by the initial $\mathrm{OD}_{600}\left(V_{\max }\right.$; Bright \& Johnstone, 1987). The extent of germination was confirmed at the end of each experiment by determining the ratio of phase-bright to phasedark spores. In all experiments the ratio of phase-bright to phase-dark spores correlated with the percentage loss of $\mathrm{OD}_{600}$.

Effect of inhibitors. The effect of D-Ala, D-Asn, $\mathrm{HgCl}_{2}$, protease inhibitors and metabolic inhibitors on germination was examined as described by Venkatasubramanian \& Johnstone (1989). Where indicated, inhibitors were added at the stated concentrations to spore suspensions at $37^{\circ} \mathrm{C} 15 \mathrm{~min}$ prior to the addition of germinants. The control germination response for inhibition studies represents that of untreated spores, for which $50-60 \%$ loss of initial $\mathrm{OD}_{600}$ was observed.

Reproducibility of results. All experiments were repeated at least twice and were internally consistent.

Chemicals. Germinants and inhibitors were from Sigma, apart from $\mathrm{HgCl}_{2}$, which was from $\mathrm{BDH}$ and of AR grade.

\section{Results and Discussion}

\section{Germination response of spores of the ger A mutant}

As described by Moir et al. (1979), spores of the gerA mutant did not germinate in the ALA system, but germinated just as well as the wild-type in the GFAK system (Fig. 1). The spores failed to germinate when the concentration of L-Ala was increased from 1 to $10 \mathrm{~mm}$ in the ALA system and the addition of Glc $\left(1 \mathrm{mg} \mathrm{ml}^{-1}\right)$ or Fru $\left(1 \mathrm{mg} \mathrm{ml}^{-1}\right)$ in the presence of 1 or $10 \mathrm{~mm}$-L-Ala did not stimulate their germination (results not shown). However, the presence of both Glc and Fru (each at $1 \mathrm{mg} \mathrm{ml}^{-1}$ ) together with $1 \mathrm{mM}-\mathrm{L}-\mathrm{Ala}$, caused $31 \% \mathrm{OD}_{600}$ loss and $50 \%$ of the spores to become phase-dark 


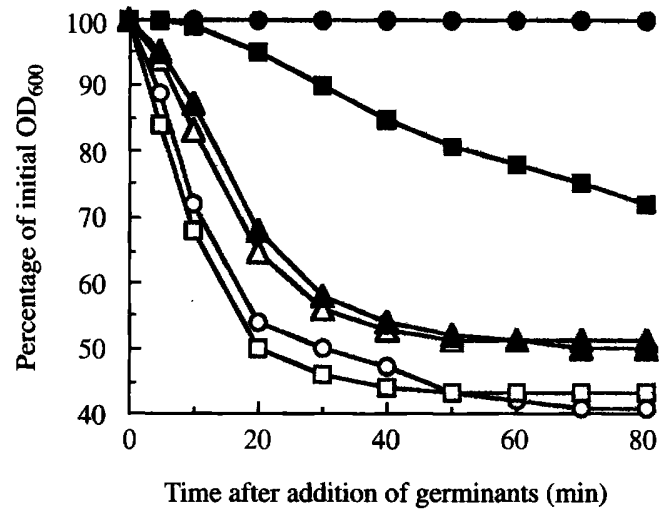

Fig. 1. Effect of Glc and Fru on ALA germination of B. subtilis 1604 and ger $A$ spores. The percentage of initial $\mathrm{OD}_{600}$ was measured during germination of $B$. subtilis $1604(O, \triangle, \square)$ and ger $A$ spores $(\boldsymbol{O}, \boldsymbol{\Delta ,} \square)$ using $\operatorname{ALA}(O, \boldsymbol{O}), \operatorname{GFAK}(\triangle, \mathbf{\Delta})$ and ALA + Glc + Fru $(\square, \boldsymbol{\square})$ as germination inducers.

(results not shown). In comparison, $>95 \%$ germination occurred when ger $A$ spores were incubated in $10 \mathrm{mM}$ $\mathrm{L}-\mathrm{Ala}+\mathrm{Glc}\left(1 \mathrm{mg} \mathrm{ml}^{-1}\right)+$ Fru $\left(1 \mathrm{mg} \mathrm{m}^{-1}\right)+50 \mathrm{mM}^{-\mathrm{K}^{+}}$ (results not shown). The rate of germination (determined as described in Methods) of ger $A$ spores increased by about three times when the concentration of L-Ala was raised from 1 to $10 \mathrm{~mm}$ while in combination with Glc, Fru and $\mathrm{K}^{+}$(GFK). These observations suggest that $\geqslant 10 \mathrm{mM}$-L-Ala can replace L-Asn in the GFAK system in this mutant. In subsequent experiments, $30 \mathrm{mM}-\mathrm{L}-\mathrm{Ala}$ was used whenever in combination with GFK (the GFAlaK system).

The $K_{\mathrm{m}}$ values for L-Ala in the GFAlaK system and LAsn in the GFAK system were determined in the ger $A$ mutant to compare the binding affinities of $\mathrm{L}-\mathrm{Ala}$ and $\mathrm{L}-$ Asn with those of the wild-type. The $K_{\mathrm{m}}$ values of L-Ala in GFAlaK $(1.1 \mathrm{mM})$ and L-Asn in GFAK $(0.9 \mathrm{mM})$ systems of the gerA mutant were similar (Fig. 2); they differed significantly from the $K_{\mathrm{m}}$ values of both L-Ala $(50 \mu \mathrm{M})$ and L-Asn $(3.3 \mathrm{mM})$ in the ALA and GFAK germination systems, respectively, of the wild-type (Venkatasubramanian \& Johnstone, 1989). This suggests either that the ger $A$ mutation has affected both the L-Ala and L-Asn receptor sites or that the L-Ala receptor in the GFAlaK system is different from that in the ALA germination system, which is presumably inactive in the ger $A$ mutant. Since $10 \mathrm{~mm}$-D-Ala completely inhibits LAla-induced germination of the wild-type spores of $B$. subtilis 1604, the effects of D-Ala and D-Asn on both the GFAK and GFAlaK germination pathways of the ger $A$ mutant were examined. Spores of the ger $A$ mutant germinated normally in the GFAK or GFAlaK systems, in the presence of D-Asn $(100-300 \mathrm{~mm})$ or D-Ala (30-300 mM) (results not shown). This suggests, therefore, that the receptor responding to L-Ala in the GFAlaK system differs from that responding to L-Ala in

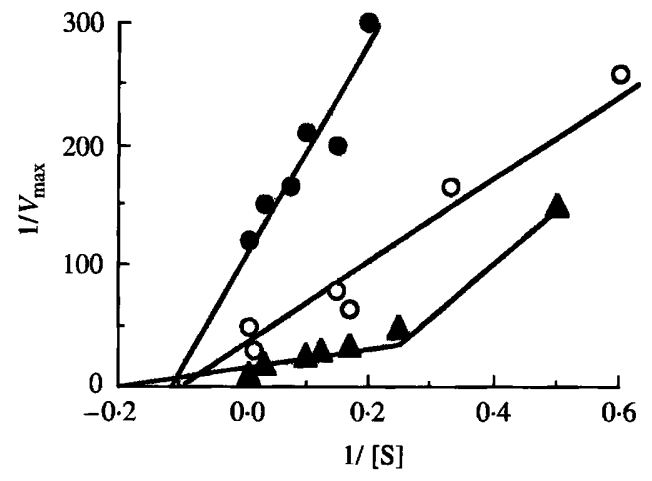

Fig. 2. Lineweaver-Burke plots for L-Ala and L-Asn during ALA, GFAK and GFAlaK germination of $B$. subtilis ger $A$ and ger $B$ spores. Spores were germinated (as described in Methods) in ALA, GFAlaK and GFAK systems. $1 /[\mathrm{S}]$ was plotted against $1 / V_{\max }$ (see Methods) for L-Ala in ALA germination of gerB spores $\left(A, 10^{-1} \times \mu \mathrm{M}^{-1}\right)$ or GFAlaK germination of ger $A$ spores $\left(O, 10^{-2} \times \mu \mathrm{M}^{-1}\right)$, and for L-Asn in GFAK germination of ger $A$ spores $\left(0,10^{-2} \times \mu \mathrm{M}^{-1}\right)$.

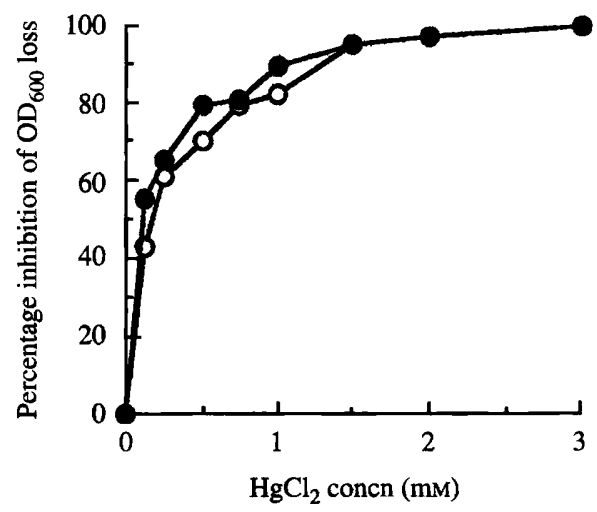

Fig. 3. Overall inhibition of GFAK and GFAlaK germination of spores of $B$. subtilis ger $A$ by $\mathrm{HgCl}_{2}$. Spores were treated with varying concentrations of $\mathrm{HgCl}_{2}$ and the percentage inhibition of $\mathrm{OD}_{600}$ loss determined as described in Methods, after germination in GFAK (O) and GFAlaK (O) for $80 \mathrm{~min}$.

the ALA pathway, since $300 \mathrm{~mm}-\mathrm{D}-\mathrm{Ala}$ completely inhibits the ALA pathway.

Since it was observed that the GFAK and ALA systems in the wild-type had different sensitivities towards $\mathrm{HgCl}_{2}, \mathrm{NaN}_{3}$ and PMSF (Venkatasubramanian \& Johnstone, 1989), the effect of these inhibitors on germination of spores of the ger $A$ mutant was studied. The overall $\mathrm{HgCl}_{2}$ inhibition profile of the GFAlaK system was similar to that of the GFAK system in the ger A mutant (Fig. 3). Although the overall inhibition of this pathway by $\mathrm{HgCl}_{2}$ was not as great as that of the GFAK system in wild-type B. subtilis 1604 (Venkatasubramanian \& Johnstone, 1989), it was more sensitive to $\mathrm{HgCl}_{2}$ than the ALA system of the wild-type (Venkatasubramanian \& Johnstone, 1989). At 0.5 mM$\mathrm{HgCl}_{2}, \mathrm{OD}_{600}$ loss was inhibited by 71 and $79 \%$ in the 
GFAK and GFAlaK systems, respectively, whereas in the wild-type $0.5 \mathrm{~mm} \mathrm{HgCl}_{2}$ inhibited $\mathrm{OD}_{600}$ loss by 61 and $>95 \%$ in the ALA and GFAK germination systems, respectively. It is not known why the $\mathrm{HgCl}_{2}$ sensitivity of the GFAK pathway is altered in the ger $A$ mutant as compared with the wild-type. As observed for the GFAK system of the wild-type, the mutant spores could be protected by either D-Asn ( $300 \mathrm{mM})$ or D-Ala $(300 \mathrm{~mm})$ from $3 \mathrm{~mm}-\mathrm{HgCl}_{2}$ to allow subsequent germination in the GFAlaK and GFAK systems. $\mathrm{NaN}_{3}$ which inhibits only GFAK germination (by $>95 \%$ ) and does not have any effect on the ALA system in the wildtype spores (Venkatasubramanian \& Johnstone, 1989), was found to inhibit both the GFAK and GFAlaK systems in spores of the ger $A$ mutant. Germination in the GFAlaK system was inhibited by $>95 \%$, whereas the GFAK system was inhibited by about $85-90 \%$ in the presence of $10 \mathrm{mM}^{-\mathrm{NaN}_{3}}$ (results not shown). PMSF ( $3.3 \mathrm{mM})$, which completely inhibits germination in the ALA system had no significant effect on the GFAK germination system of the wild-type spores (Venkatasubramanian \& Johnstone, 1989) and had no effect on either the GFAlaK or GFAK systems of the ger $A$ mutant. These results are therefore consistent with the hypothesis that a new pathway in which L-Ala can substitute for L-Asn in GFAK (the GFAlaK pathway) exists. These results also suggest that although germination in the ALA and GFAK systems has been considered to be due to 'independent' pathways, the germinant receptors for L-Ala, Glc, Fru and L-Asn are capable of interacting with one another. The characterization of ger $A$ mutants which responded to ALA + Glc, ALA + Fru or needed ALA and both Glc + Fru (Moir et al., 1979; Sammons et al., 1981; Trowsdale \& Smith, 1975; Wax \& Freese, 1968) also supports this view. It has been shown also that temperature-sensitive ALA germination of a ger $A$ mutant of $B$. subtilis 168 at $43{ }^{\circ} \mathrm{C}$ is rectified by the addition of Fru, and that Glc enhances the reversion (Irie et al., 1982). One explanation for the different phenotypes of ger $A$ mutants is that their mutations cause defects in the germinant receptor which affect the binding site in different ways. The observation that a mutant defective in Glc ( $\mathrm{gerK})$ is able to affect both the ALA and GFAK responses (Irie et al., 1982) is another indication that an interaction occurs between the receptors of L-Ala, Glc, Fru and L-Asn.

There have been previous hypotheses that two L-Ala receptors are involved in $B$. subtilis spore germination (Irie et al., 1982; Sammons et al., 1981). The present study is in agreement with these suggestions and provides firm evidence for the presence of an L-Ala receptor which is stimulated during ALA germination, and another which requires a higher concentration of L-Ala, as well as

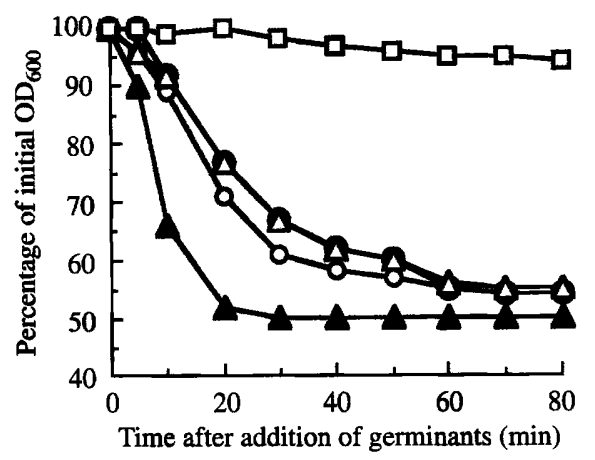

Fig. 4. Germination of $B$. subtilis ger $B$ spores in the ALA and GFAK systems and the effect of Glc and Fru on ALA germination. Spores of ger $B$ were treated with ALA (O), ALA + Glc (O), ALA + Fru ( $\triangle$ ), ALA + Glc + Fru (A) and GFAK ( $\square$ ), and the percentage of initial $\mathrm{OD}_{600}$ determined as described in Methods.

the presence of Glc + Fru for its stimulation. The second type of receptor may be the same as the L-Asn receptor and therefore this receptor is termed the L-Ala/L-Asn receptor. The presence of this receptor suggests that the observed reversal of D-Ala inhibition by Glc and Fru, previously thought to be due to stimulation of the ALA pathway (Wax et al., 1967), is probably simply a result of stimulation of the GFAlaK pathway.

\section{Germination response of spores of the ger B18 mutant}

Spores of the $\operatorname{ger} B$ mutant failed to germinate in the GFAK system, but germinated just as well as the wildtype in the ALA system (Fig. 4) as reported by Moir et al. (1979). The rate of germination in the ALA system increased in the presence of Glc $\left(1 \mathrm{mg} \mathrm{ml}^{-1}\right)$ or Glc $\left(1 \mathrm{mg} \mathrm{ml}^{-1}\right)+$ Fru $\left(1 \mathrm{mg} \mathrm{ml}^{-1}\right)$, whereas it remained the same in the L-Ala + Fru (1 mg ml$\left.{ }^{-1}\right)$ combination (Fig. 4). Thus Fru can only assist Glc in enhancing the rate of ALA germination and the germination defect in the ger $B$ mutant therefore appears to be associated with the L-Asn receptor.

To determine whether the ger $B$ mutation had affected L-Ala binding to the L-Ala receptor, the $K_{\mathrm{m}}$ value for LAla in the ALA system was determined. The $K_{\mathrm{m}}$ value of L-Ala was $50 \mu \mathrm{M}$ for both the wild-type (Venkatasubramanian \& Johnstone, 1989) and the ger $B$ mutant (Fig. 2). The mutation in the ger $B$ mutant does not therefore appear to have changed the binding constant of the L-Ala receptor. Moreover, as observed in the wildtype, there was a departure from Michaelis-Menten kinetics in the low L-Ala concentration range for $\operatorname{ger} B$ spores (Venkatasubramanian \& Johnstone, 1989; Fig. 2).

Since the use of D-amino acids as inhibitors of germination can indicate the specificity of the receptor site, spores of the ger $B$ mutant were allowed to germinate 


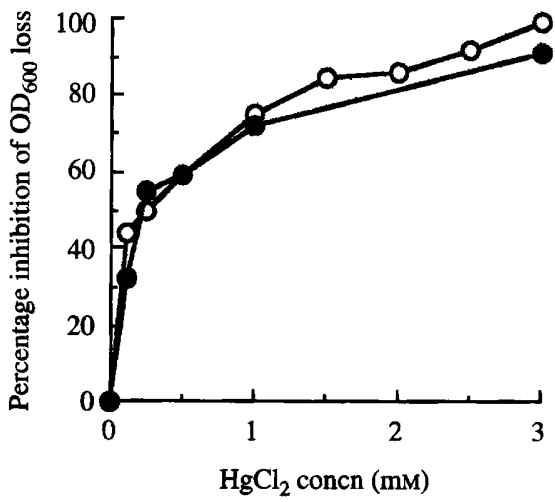

Fig. 5. Effect of $\mathrm{Glc}+\mathrm{Fru}$ on the overall $\mathrm{HgCl}_{2}$ inhibition of ALA germination of $B$. subtilis gerB spores. Spores were treated with $\mathrm{HgCl}_{2}$ and germinated with ALA in the presence $(O)$ and absence $(O)$ of $\mathrm{Glc}+$ Fru. The percentage inhibition of $\mathrm{OD}_{600}$ loss was determined as described in Methods.

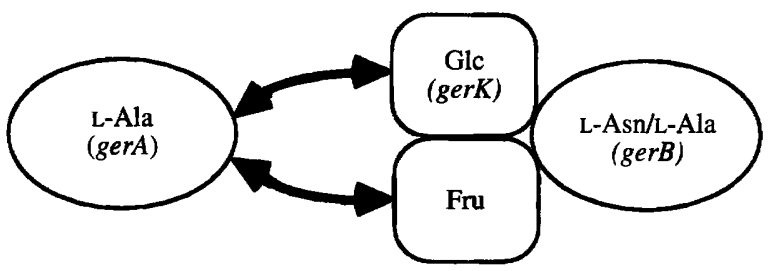

Fig. 6. Model showing proposed functional interactions between the L-Ala, L-Asn, Glc and Fru germinant receptors in the B. subtilis ALA, GFAK and GFAlaK spore germination pathways. The corresponding germination loci are given in italics.

in the ALA system in the presence of D-Ala (10-300 mM) and D-Asn (10-300 mM). In the presence of $10 \mathrm{mM}-\mathrm{D}$ Ala, no germination of ger $B$ spores occurred in the ALA system, whereas the presence of 10-300 mM-D-Asn had no effect in the ALA system (results not shown). Partial reversibility of D-Ala inhibition by Fru, and enhancement of the reversion by Glc has been noted in B. subtilis 168 strain 127 (Wax et al., 1967). Experiments were therefore carried out to test whether Glc, Fru or Glc + Fru could reverse inhibition by $10 \mathrm{mM}-\mathrm{D}-\mathrm{Ala}$ in germination in the ALA system in both wild-type and ger $B$ spores. It was observed that in the wild-type neither Glc nor Fru reversed D-Ala inhibition individually, but that Glc + Fru in combination reversed this inhibition by $40 \%$ (results not shown). In the ger $B$ mutant, this inhibition was not reversed at all by Glc, Fru or Glc + Fru. This further suggests that the L-Ala/L-Asn receptor in the $\operatorname{ger} B$ mutant is deficient in its interaction with the Glc and/or Fru receptor.

The overall effect of $\mathrm{HgCl}_{2}$ on inhibition of ger $B$ spore germination in the ALA system was similar to that observed in the wild-type (Fig. 5; Venkatasubramanian $\&$ Johnstone, 1989). In both the wild-type and the ger $B$ mutant, $0.5 \mathrm{~mm}-\mathrm{HgCl}_{2}$ inhibited germination in the ALA system by about $55-60 \%$ and $3 \mathrm{mM}-\mathrm{HgCl}_{2}$ inhibited germination by $>95 \%$. PMSF ( $3.3 \mathrm{~mm}$ ) inhibited ALA germination of ger $B$ spores completely as observed in wild-type spores (Venkatasubramanian \& Johnstone, 1989). Since germination of ger $A$ spores in the GFAK and GFAlaK systems and germination of ger $B$ spores in the ALA system differed in their sensitivity towards $\mathrm{HgCl}_{2}$ and PMSF, it is possible that the differences in sensitivity may be due to the presence of Glc and/or Fru rather than to the presence of the amino acid component of the germinant system. Therefore, the overall inhibition of germination of $\mathrm{ger} B$ spores by $\mathrm{HgCl}_{2}, \mathrm{NaN}_{3}$ and PMSF was studied after the addition of Glc + Fru to the ALA system. It was observed that the presence of $\mathrm{ALA}+\mathrm{Glc}+\mathrm{Fru}$ did not make the ger $B$ spores more sensitive to $\mathrm{HgCl}_{2}\left(3 \mathrm{mM}-\mathrm{HgCl}_{2}\right.$ inhibited germination by $92 \%$; Fig. 5). Similarly, the presence of Glc + Fru did not affect the sensitivity of ger $B$ spores in the ALA system to PMSF or to $\mathrm{NaN}_{3}$. PMSF $(3.3 \mathrm{~mm})$ still inhibited germination by greater than $95 \%$ and $10 \mathrm{mM}-$ $\mathrm{NaN}_{3}$ had no effect on ALA germination of the gerB mutant (results not shown). Thus, the presence of Glc + Fru did not appear to be the cause of differential sensitivity of the ALA and GFAK systems to $\mathrm{HgCl}_{2}$ and PMSF in the ger $B$ mutant.

\section{A model for the interaction of germinant receptors in B. subtilis}

Based on the results of the present study of ger $A$ and ger $B$ mutants and earlier work (Irie et al., 1982; Moir et al., 1979; Sammons et al., 1981), a model showing interaction of the receptor sites for L-Ala, Glc, Fru and L-Asn is proposed in Fig. 6. In this model, the L-Ala, Glc, Fru and L-Asn receptors are in close proximity to one another since they can functionally interact. The L-Asn receptor in this complex can also be activated by L-Ala at high concentrations, has similar germination requirements and hence has been called the L-Ala/L-Asn receptor. It is also proposed that ger $A$, ger $B$ and ger $K$ encode the L-Ala, L-Asn and Glc receptors, respectively.

The gene encoding a putative L-Ala receptor which responds to L-Ala has been cloned and sequenced (Feavers et al., 1985; Zuberi et al., 1985, 1987). It will be interesting to sequence the genes encoding the other germinant receptors as well as to analyse the germination response of spores of $\operatorname{ger} B$ deletion mutants to gain a better understanding of the germinant receptor complex in B. subtilis 1604. In addition, site-directed mutagenesis of the ger genes may allow the functional domains of the receptors and their interactions to be studied further.

We are grateful to the Nehru Trust for Cambridge University for financial support (P.V.) and to Drs S. J. Foster and A. Moir for invaluable discussions. 


\section{References}

BRIGHT, J. J. \& JOHNSTONE, K. (1987). Germination kinetics of spores of Clostridium bifermentans M86b. Microbios 52, 17-28.

Feavers, I. M., Miles, J.S. \& MoIR, A. (1985). The nucleotidesequence of a spore germination gene ( $g e r A$ ) of Bacillus subtilis 168 . Gene 38, 95-102.

FosteR, S. J. \& JOHNSTONE, K. (1989). The trigger mechanism of bacterial spore germination. In Regulation of Prokaryotic Development, pp. 89-108. Edited by I. Smith, R. A. Slepecky \& P. Setlow. Washington, D.C.: American Society for Microbiology.

FreEse, E. \& CASHFL, M. (1965). Initial stages of germination. In Spores III, pp. 144-151. Edited by L. L. Campbell \& H. O. Halvorson. Ann Arbor, Michigan: American Society for Microbiology.

FreEse, E. \& ForTNAGel, U. (1969). Growth and sporulation of Bacillus subtilis mutants blocked in the pyruvate dehydrogenase complex. Journal of Bacteriology 99, 745-756.

IRIE, R., OKAMOTO, T. \& FujITA, Y. (1980). Initiation of germination of Bacillus subtilis spores by allylglycine. Journal of General and Applied Microbiology 26, 425-428.

IRIE, R., OKamoto, T. \& FuJita, Y. (1982). A germination mutant of Bacillus subtilis deficient in response to glucose. Journal of General and Applied Microbiology 28, 345-354.

KANDA, K., YaSUdA, Y. \& TochiKubO, K. (1988). Germinationinitiating activities for Bacillus spores of analogues of L-alanine derived by modification at the amino or carboxyl group. Journal of General Microbiology 134, 2747-2755.

LAFFERTY, E. \& MoIR, A. (1977). Further studies on conditional germination mutants of Bacillus subtilis 168. In Spore Research 1976, pp. 87-105. Edited by A. N. Barker, G. J. Dring, D. J. Ellar, G. W. Gould \& J. Wolf. London: Academic Press.

MorR, A. \& SMITH, D. A. (1985). The genetics of spore germination in Bacillus subtilis. In Fundamental and Applied Aspects of Bacterial Spores, pp. 89-100. Edited by G. J. Dring, D. J. Ellar \& G. W. Gould. London: Academic Press.

MoIR, A. \& SMITH, D. A. (1990). The genetics of bacterial spore germination. Annual Review of Microbiology 44, 531-553.

MoIR, A., LAfFerTY, E. \& SMTt, D. A. (1979). Genetic analysis of spore germination mutants of Bacillus subtilis 168: the correlation of phenotype with map location. Journal of General Microbiology 111, 165-180.

Prasad, C., Diesterhaft, M. \& Freese, E. (1972). Initiation of spore germination in glycolytic mutants of Bacillus subtilis. Journal of Bacteriology 110, 321-328.

RATHER, P. N. \& MoRAN, C. P. (1988). Compartment-specific transcription in Bacillus subtilis: identification of the promoter for $g d h$. Journal of Bacteriology 170, 5086-5092.

SAMmons, R. L., MoIR, A. \& SMITH, D. A. (1981). Isolation and properties of spore germination mutants of Bacillus subtilis 168 deficient in the initiation of germination. Journal of General Microbiology 124, 229-241.
SMITH, D. A., MoIr, A. \& LAFFERTY, E. (1977). Spore germination genetics in Bacillus subtilis. In Spore Research 1976, pp. 69-85. Edited by A. N. Barker, G. J. Dring, D. J. Ellar, G. W. Gould \& J. Wolf. London: Academic Press.

Stewart, G. S. A. B., Johnstone, K., Hagelberg, E. \& Ellar, D. J. (1981). Commitment of bacterial spores to germinate: a measure of the trigger reaction. Biochemical Journal 198, 101-106.

Strauss, N. (1983). Role of glucose dehydrogenase in germination of Bacillus subtilis spores. FEMS Microbiology Letters 20, 379-384.

Trowsdale, J. \& SMITH, D. A. (1975). Isolation, characterization and mapping of Bacillus subtilis 168 germination mutants. Journal of Bacteriology 123, 83-95.

Venkatasubramanian, P. \& Johnstone, K. (1989). Biochemical analysis of the Bacillus subtilis 1604 spore germination response. Journal of General Microbiology 135, 2723-2733.

WAX, R. \& FREESE, E. (1968). Initiation of the germination of Bacillus subtilis spores by combination of compounds in place of L-alanine. Journal of Bacteriology 95, 433-438.

WAX, R., FREESE, E. \& CASHEL, M. (1967). Separation of two functional roles of L-alanine in the initiation of Bacillus subtilis spore germination. Journal of Bacteriology 94, 522-529.

WoEse, C. R., Morowitz, H. J. \& HuTChISON, C. A. (1958). Analysis of action of L-alanine analogues in spore germination. Journal of Bacteriology 76, 578-588.

Wolgamott, G. D. \& Durham, N. N. (1971). Initiation of spore germination in Bacillus cereus: a proposed allosteric receptor. Canadian Journal of Microbiology 17, 1043-1048.

YASUDA, Y. \& ToCHIKUBO, K. (1984). Relation between D-glucose and $\mathrm{L}$-alanine and D-alanine in the initiation of germination of Bacillus subtilis spores. Microbiology and Immunology 28, 197-207.

YASUDA, Y. \& ToCHIKUBO, K. (1985). Germination-initiation and inhibitory activities of L-alanine and D-alanine analogs for Bacillus subtilis spores - modification of methyl-group of L-alanine and Dalanine. Microbiology and Immunology 29, 229-241.

YASUDA, Y., NAMIKI-KANIE, S. \& HACHISUKA, Y. (1978a). Inhibition of germination of Bacillus subtilis spores by alcohols. In Spores VII, pp. 104-108. Edited by G. Chambliss \& J. C. Vary. Washington, D.C.: American Society for Microbiology.

YASUDA, Y., NAMIKI-KANIE, S. \& HACHISUKA, Y. (1987b). Inhibition of Bacillus subtilis spore germination by various hydrophobic compounds: demonstration of hydrophobic character of the L-alanine receptor site. Journal of Bacteriology 136, 484-490.

YasudA, Y., Tochikubo, K., HachisuKa, Y., TOMida, H. \& IKEDA, K. (1982). Quantitative structure-inhibitory activity relationships of phenols and fatty acids for Bacillus subtilis spore germination. Journal of Medicinal Chemistry 25, 315-320.

ZuBERI, A. R., FeAVERs, I. M. \& MOIR, A. (1985). Identification of three complementation units in the ger $A$ spore germination locus of Bacillus subtilis. Journal of Bacteriology 162, 756-762.

Zuberi, A. R., MoIR, A. \& Feavers, I. M. (1987). The nucleotidesequence and gene organization of the ger $A$ spore germination operon of Bacillus subtilis 168. Gene 51, 1-11. 